\title{
LEGAL AND ECONOMIC ASPECTS OF MONETARY REGULATION OF THE EUROPEAN SYSTEM OF CENTRAL BANKS
}

\author{
Viacheslav Tuliakov* \\ Halyna Alekseievska** \\ Sergey Yakubovsky ${ }^{* * *}$
}

\begin{abstract}
Monetary regulation is one of the most important components of government policy. The monetary regulation policy of the European Central Bank has undergone important transformations over the past ten years as a result of measures that were taken in response to the global financial crisis of 2008. Today the main problem of the ECB is not inflation, but stimulation of the post-crisis development of European countries. As a result, many new elements have been added to the ideology and practice of monetary regulation. Moreover, new challenges, such as a pandemic, are prompting the ECB to seek new means of influencing financial markets and, ultimately, the real sector of the economy.
\end{abstract}

The paper presents the modern system of monetary regulation in the EU, characterizes its structure and legal status. The consequences of the application of unconventional measures of monetary regulation in the EU in the period after the 2008 crisis and during the COVID 19 crisis were determined. The effectiveness of the ECB's actions in overcoming the crisis was analyzed. On the example of the decision of the Federal Constitutional Court of Germany, the reasons were identified and the consequences of the conflict between the EU legislation and national legislation in the issue of the jurisdiction of monetary regulation were assessed.

KEYWORDS: monetary regulation, legal regulations, unconventional instruments, COVID 19 pandemic, contradictions between EU law and national legislation.

\footnotetext{
Viacheslav Tuliakov, National University Odessa Law Academy, Odessa, Ukraine; tuliakov @onua.edu.ua.

** Halyna Alekseievska, Odessa I. I. Mechnikov National University, Odessa, Ukraine; g.alex @onu.edu.ua.

*** Sergey Yakubovsky, Odessa I. I. Mechnikov National University, Odessa, Ukraine; syakubovskiy@onu.edu.ua.
} 


\section{INTRODUCTION}

The strengthening of the importance of monetary regulation in the conditions of globalization, financial deregulation, and the persistence of crises actualizes the study of the features of methods and tools for its implementation. Studying the effectiveness of monetary regulation and its impact and role in overcoming structural imbalances in the economy of the country is important for any state.

The theoretical basis of monetary regulation is monetary theory. Modern theories took shape only in the 1930s. Keynesian approaches and monetarism are fundamental. Subsequently, theories such as the neoclassical theory of the business cycle, the neo-Keynesian methodology, and the new consensus model (NCM), which have been at the center of the analysis of monetary policy over the past decades, were formed on the basis of these two directions ${ }^{1} .^{2}$

But despite the development of various theories in the economic literature, there are still discussions regarding the concept of the essence of monetary regulation. For example, M. Friedman and his followers regard monetary regulation as a set of purposeful and coordinated actions of monetary authorities to regulate the volume of money supply in the economy. E. J. Dolan refers to monetary policy as all government actions that affect the amount of money in circulation ${ }^{3}$. Some researchers believe that the system of monetary regulation of the state is aimed at providing a market economy with compulsory mechanisms and instruments that are used by the system of public administration to effectively manage the national economy while others consider monetary regulation as a source of economic shifts that lead to higher real income and living standards of the population; it acts as a measure of restraining inflationary processes that meets the main objectives of monetary policy. ${ }^{4}$

A great contribution to the study of monetary regulation in the European Union was made by many scientists: whose work analyzes the impact of ECB measures to provide liquidity on rates on interbank loans with a maximum

\footnotetext{
1 Arestis, P.; Sawyer, M.: A Critical reconsideration of the foundations of monetary policy in the new consensus macroeconomic framework, Cambridge Journal of Economics, 322008 , p. 5 .

2 Kovalenko, V.et al.: Monetary regulation in the economic growth of a state. Financial and credit activities: problems of theory and practice, 3 (34) 2020, p. 70-80.

3 Yakubovskiy, S.; Alekseievska, H.; Tsevukh J.: Impact of the European Central Bank Monetary Policy on the Financial Indicators of the Eastern European Countries. Journal Global Policy and Governance, 9 (1) 2020. [htps://doi.org/10.14666/2194-7759-9-1-003]

4 Kovalenko, V.; Sheludko, S.; Slatvinska, M.; Sergeeva O.; Kulikova Ye: Monetary regulation in the economic growth of a state. Financial and credit activities: problems of theory and practice, 3 (34) 2020, p. 70-80.
} 
maturity of up to 12 months $^{5}$; investigated the development and features of the ECB's monetary policy. ${ }^{6} 7$ 8; identified the main factors influencing the return on assets in the EU countries as well as in the emerging market economies ${ }^{91011}$; study inflationary processes in the euro area and come to the conclusion that a long period of low inflation has several negative consequences for the Euro$z^{2} e^{12}{ }^{13}$; study the impact of unconventional methods of monetary regulation on social-economic development of the EU countries, and came to the conclusion that unconventional methods of monetary regulation had a significant impact on interest rates, inflation and stimulated economic growth ${ }^{14}{ }^{15}$ 16; study economic and monetary regulation at the supranational and national levels. ${ }^{17}$

5 Abbassi, P.; Linzert T.: The effectiveness of monetary policy in steering money market rates during the financial crisis, Journal of Macroeconomics, 34 2012, p. 945-954.

6 Burriel, P.; Galesi, A.: Uncovering the heterogeneous effects of ECB unconventional monetary policies across euro area countries, European Economic Review, 101 2018, p. 210-229.

7 Elbourne, A.; Ji K.; Duijndam S.: The effects of unconventional monetary policy in the euro area. CPB Discussion Paper, 371 2018, p. 1-36.

8 Gambetti, L.; Musso, A.: The macroeconomic impact of the ECB's expanded asset purchase programme (APP). European Central Bank Working Paper Series, 2075 2017, p. 1-43.

9 Dominese, G., Yakubovskiy, S., Rodionova, T., Derenko, V. Determinants of the government bond yields of Italy, Spain, Portugal and Greece. Journal Global Policy and Governance, 10(1) 2021, [https://doi.org/10.14666/2194-7759-10-1-002] p. 23-34.

10 Dominese G., Rodionova T., Tsviakh A. Comparative Analysis of the Return on Foreign Investments of the United States, Germany and Japan. Journal Global Policies and Governance, 9(2) 2020, [https://doi.org/10.14666/2194-7759-9-2-002] p. 17-27.

11 Lomachynska, I., Babenko, V., Yemets Impact of the Foreign Direct Investment Inflow on the Export Growth of the Visegrad Group Countries. Studies of Applied Economics, [http:// dx.doi.org/10.25115/eea.v38i4.4007] 38 (4) 2020.

12 Ciccarelli, M., Garc'ia, J. A., Montes-Gald'on, C.: Unconventional monetary policy and the anchoring of inflation expectations. European Central Bank Technical Report, 1995 2017, p. 1-33.

13 Asshoff, S.; Belke, A.; Osowski, T.: Unconventional monetary policy and inflation expectations in the Euro area, CEPS Working Documents, 1 2020, p. 1-35.

14 Acharya, V.; Eisert, T.; Eufinger, C.; Hirsch C.: Whatever it takes: The real effects of unconventional monetary policy, The Review of Financial Studies, 32 (9) 2019, p. 3366-3411.

15 Mouabbi, S., Sahuc, J. G. Evaluating the macroeconomic effects of the ECB's unconventional monetary policies. Journal of Money, Credit and Banking. 51 (4) 2019, p. 831-858.

16 Zabala, J. A.; Prats, M. A.: The unconventional monetary policy of the European Central Bank: Effectiveness and transmission analysis. The World Economy, 43 2019, [https://doi. org/10.1111/twec.12880]

17 Holman O.: Asymmetrical regulation and multidimensional governance in the European Union. Review of International Political Economy, 2024, [10.1080/096922904200027977] p. 714-735. 
${ }^{18}$ The authors noting the principle of dual additivity ${ }^{19}$ tried to prove that these are two sides of the same coin. Since in order to improve the level of competitiveness of the EU countries, the adoption of economic and monetary decisions goes beyond the framework of national states and democratic responsibility.

At the same time, for all the breadth and depth of research in the field of monetary regulation, they are not exhaustive, since the speed of changes in the world community and the economic situation requires a constant deepening of existing and development of new research.

\section{METHODOLOGY}

The following general scientific and special methods and approaches were applied in the work: systemic-structural approach, comparative analysis for comparing stages, processes, phenomena, identifying general and specific, to study the causes of changes and identify trends in the development of monetary regulation in the EU, methods of statistical analysis - to assess the dynamics of indicators of economic development and stability of the financial system, as well as formal legal, comparative, historical methods. The theoretical and methodological basis of the study is the scientific works of leading foreign and domestic scientists, revealing the essence and mechanisms of the EU monetary policy, legal acts, and regulations of the ECB.

\section{RESULTS AND DISCUSSION}

\subsection{FUNDAMENTALS OF MONETARY REGULATION IN THE EU}

The development and establishment of monetary regulation in each country go through different stages of transformation, but the formation of the system of monetary regulation of the Eurozone is a unique case because the ECB is the central bank of more than one country.

The creation of the European System of Central Banks (ESCB) was an institutional innovation of the Maastricht Treaty. In the process of the creation of the European Monetary System, monetary cooperation between the member states has intensified, the ties between national central banks have become more and more strengthened. All this led to the development of rules for the

18 Carstensen, M. B,; Schmidt, V. A.: Power and changing modes of governance in the euro crisis, Governance, 31 2017, [10.1111/gove.12318] p. 609-624.

19 Tuliakov V. A.: The dualism of business victimization and organized crime, Trends in Organized Crime,6, 2001 [https://doi.org/10.1007/s12117-001-1008-4] p. 94-99. 
joint regulation of the monetary policies of the member states and the creation of the Unified System of European Banks, in which the responsibility for the implementation of the unified monetary policy was transferred to the European Central Bank.

At the same time, the independence of central banks is a fundamental aspect of the successful organization of monetary regulation in the Eurozone. The provision on the independence of central banks from national governments and pan-European institutions is enshrined in Article 108 of the Treaty on the European Union ${ }^{20} 21$

Monetary regulation in the European Economic and Monetary Union is carried out by the European System of Central Banks (ESCB), which includes the European Central Bank (ECB) and the national central banks of the member states. The legal status of the ESCB is determined by the Treaty on the Functioning of the EU and the Statute of the European System of Central Banks and the European Central Bank. ${ }^{22}$ The ESCB also includes the central banks of countries outside the euro area. They retain their monetary sovereignty, continue to use the national currency, and pursue an independent monetary policy. However, these states have the same monetary policy goal as the ECB - to ensure price stability, and they closely interact with the ESCB in the collection of statistical information.

The ESCB was created by Article 108 of the Treaty establishing the European Community and is the constitutional body of the EU. The ESCB acts following the principle of an open market economy with free competition, promoting the efficient allocation of resources (Article 127 (1) Treaty on the Functioning of the European Union). ${ }^{23}{ }^{24}$ As expected, the European system of central banks should independently exercise monetary regulation. In this regard, it was necessary to create the most effective structure of decision-making bodies. ${ }^{25}$ As a result, the Governing Council and the Board of the ECB became such bodies.

\footnotetext{
${ }^{20}$ [http://eur-lex.europa.eu/legal-content/EN/TXT/PDF/?uri=CELEX:12002E/TXT\&from=EN] accessed on 09/07/2021.

21 Salter, A. W.: An Introduction to Monetary Policy Rules. Mercatus Working Paper, 12(04) 2014, [http://dx.doi.org/10.2139/ssrn.3191382], p. 1-41.

22 -[https://eur-lex.europa.eu/legal-content/EN/TXT/HTML/?uri=CELEX:12016E/ PRO/04\&from=EN] accessed on 09/07/2021.

23 -[http://eur-lex.europa.eu/legal-content/EN/TXT/PDF/?uri=CELEX:31964D0300\&from=EN]

24 [http://europa.eu/eu-law/decision-making/treaties/pdf/treaty_on_european_union/treaty_ on_european_union_en.pdf] accessed on 09/07/2021.

25 -[http://aei.pitt.edu/1002/1/monetary_werner_final.pdf] accessed on 19/07/2021.
} 
The Board of the ECB plays a major role in the preparation and implementation of decisions and specific measures of monetary policy, while the Governing Council formulates monetary policy based on a generalized assessment of the economic situation and sets the necessary benchmarks for its implementation. National central banks play the role of self-governing elements in the structure. Also, in this system, technical committees are consisting of highly qualified specialists from the ECB and national central banks. The committees coordinate the implementation of their tasks by the national central banks and also provide assistance to the governing bodies. ${ }^{26}$

This structure of the European System of Central Banks leads to a high level of decentralization. The principle of decentralization is enshrined in the Statute of the ESCB. According to this principle, the decision-making process is carried out centrally, and the implementation of monetary policy by national banks is decentralized. National central banks perform virtually all operational tasks independently. ${ }^{27}$

In the field of international cooperation, the European Central Bank acts as a representative of the Eurosystem. External operations of national central banks are authorized by the ECB. Among such transactions - the establishment of relations with foreign financial institutions and international organizations, the acquisition and sale of assets in foreign currency.

Control over the activities of the ESCB is exercised by the European Parliament, the European Commission, and the Council of Ministers. The ECB provides these institutions with reports on their own work and the functioning of the Eurosystem. In addition, it ensures that the population is regularly informed about its activities.

\subsection{LEGAL DIFFERENCES IN THE FRAMEWORK OF MONETARY REGULATION IN THE EU IN 2008-2019}

Formally, the main goal of monetary regulation of the European system of central banks is to maintain price stability, which is determined using quantitative characteristics, in particular, the inflation rate should not exceed $2 \%$ in the medium term. The main purpose of the ESCB is spelled out in Article 127 Treaty on the Functioning of the European Union. Without prejudice to this aim, the ESCB supports the common economic policy of the Union. In addition, the competence of the Central Bank also includes control of the exchange

\footnotetext{
26 -[https://eur-lex.europa.eu/legal-content/EN/TXT/HTML/?uri=CELEX:12016E/PRO/04 $\&$ from $=\mathrm{EN}]$ accessed on 09/07/2021.

27 Piodi F.: The long road to the euro. Cardoc Journals, 8 2012, p. 1-252.
} 
rate and ensuring the stability of the currency. ${ }^{28}$ To achieve this goal, central banks apply various monetary policy instruments.

Until 2008, the European Central Bank did not intervene in the real sector of the economy, and the main instrument of monetary regulation was the management of interest rates and an orientation towards controlling inflation. But in order to overcome the consequences of the global financial crisis, the ECB began to apply traditional methods, but they turned out to be ineffective in overcoming the banking crisis, by the end of 2009, the ECB's interest rates were reduced to almost their minimum (MRO April 2009-1.25\%), operations on the open market did not give the desired effect, and the inflation rate was rapidly declining and by the end of 2009 deflationary processes were already observed. In these circumstances, the ECB had to change its traditional position and apply unconventional monetary policy instruments.

The first action by the European Central Bank was to increase the number and variety of long-term refinancing operations (LTRO). In normal times, financial institutions borrow from the ECB through regular open market transactions with maturities of 7 days, these are basic refinancing operations or three-month LTROs. And in crisis conditions, the ECB introduced special refinancing operations for 6, 12, 24, and 36 months.

In May 2009, the ECB announced the Covered Bond Purchase Program (CBPP1), under which private sector bonds were purchased. Thanks to the active policy of the ECB, by 2010 it was possible to achieve some stabilization of the economic situation in the eurozone, although later many member countries formed significant budget deficits. And this led to a significant gap between the yields of government bonds of the countries of the Eurozone, interest rates on bonds of countries with less developed economies rose, while interest rates on bonds of countries such as Germany and France fell. Accordingly, in the financial markets, government bonds of countries were no longer considered the same in terms of their reliability. ${ }^{29}$

European Central Bank began to act as the lender of last resort for sovereign debt markets for resolve the crisis. Thus, in October 2011, the second round of the Covered Bond Purchase Program (CBPP2) was launched. However, the crisis continued to intensify, putting the Eurozone at risk of collapse. President of the European Central Bank, Mario Draghi in his speech on July 25, 2012,

\footnotetext{
28 [https://www.ecb.europa.eu/mopo/html/index.en.html] accessed on 16/07/2021.

29 Alekseievska, H. et al.: Modeling Outcomes of Unconventional Monetary Policy, International Journal of Recent Technology and Engineering (IJRTE). 1(4) 2019, [10.35940/ijrte. D4503.118419], p. 10263-10268.
} 
said that the ECB is ready to take all necessary measures to preserve the single currency. ${ }^{30}$

All the previously described actions were not enough to fully stabilize financial markets, although there has been a slight improvement since 2013. And as a result, the ECB in June 2014 applied another unconventional method - negative interest rates. As a result, deposit rates were reduced to $-1 \%$, and today they are still negative. And also in September 2014, the ECB announced a quantitative easing program, with the aim of revitalizing certain market segments, facilitating the provision of loans, stimulating investment and, ultimately, supporting economic growth. In particular, on October 20, 2014, the ECB began buying bonds under the new Covered Bond Purchase Program (CBPP3), and on November 21, 2014, the Asset-Backed Securities Purchase Program (ABSPP) started, in March 2015, the Public Sector Asset Purchase Program (PSPP) was launched, which included purchases of sovereign bonds from the Eurozone countries and supranational European institutions, and in March 2016 the ECB launched the Corporate Sector Assets Purchase Program (CSPP). ${ }^{31} 32$

Thanks to the non-traditional measures of the ECB, until 2020, it was possible to overcome the consequences of crisis situations, revive the economy, reduce the volume of operations and show that this institution provides the necessary level of cooperation between representatives of different states, having proved its effectiveness in the development of effective and timely decisions. The ECB's unconventional monetary policy has had a significant impact on the financial performance of the eurozone. The increase in the ECB balance sheet had a weighty influence on the long-term government bonds of Greece, the yield of which expressively decreased. Also significantly influenced by inflation trends, which increased and the euro exchange rate, which strengthened.

Asset buying programs have helped to stimulate the economy after the debt crisis in the Eurozone, but at the same time they have make many doubts and precedents from a legal point of view. In particular, the unveiling of the asset purchase programs launched by the ECB in 2015 with the support of member states such as Germany have become a source of controversy. In 2017, some justices of the German Federal Constitutional Court opened a case expressing concern that a specific part of the bond buying program, the Public Sector

30 -[https://www.ecb.europa.eu/press/key/date/2012/html/sp120726.en.html] accessed on 09/07/2021.

31 -[https://www.ecb.europa.eu/mopo/html/index.en.html ] accessed on 16/07/2021.

32 Alekseievska, H.; Mumladze, A.: Quantitative Easing as The Main Instrument of Unconventional Monetary Policy, Three Seas Economic Journal, 1 2020, [https://doi.org/10.30525/ 2661-5150/2020-1-7], p. 39-46 
Procurement Program (PSPP), may be directly involved in economic policy, which the ECB is officially not allowed to do.

The European Court of Justice considered the case and in December 2018 ruled that the ECB's decision to purchase sovereign bonds was valid and within the bank's mandate, despite concerns expressed in Germany. However, fears remained in Karlsruhe all the time. In 2020, the German Constitutional Court (BVerfG) again upheld several complaints about the ECB's bond buying program, but did not cover the new coronavirus policy. ${ }^{33}$

The court ruling says the program is outside the ECB's mandate and says the German central bank must withdraw from the scheme within three months unless the ECB proves within three months that its purchase of public debt was not "disproportionate." All the necessary documents were submitted by the ECB and in the end the court ruled that the purchase of government bonds by the European Central Bank was carried out properly. ${ }^{3435}$

In this regard, the European Commission was ready to launch a case to confirm the supremacy of the EU courts over the decisions of the Federal Constitutional Court of Germany. Brussels said the Frankfurt-based ECB is governed by EU law, not Germany. The decision of the constitutional judges in Karlsruhe is believed to have jeopardized the EU's legal order by challenging the position of the High Court of the association. ${ }^{36}$ At the beginning of December 2021, European Commission has decided to close the infringement procedure against Germany regarding the aforenamed judgment of the German Constitutional Court of 5 May 2020, related to the Public Sector Asset Purchase Program of the European Central Bank. The arguments were based in particular on formal Germany's declaration of recognizing the principles of autonomy,

\footnotetext{
33 -[https://www.dw.com/en/top-german-court-says-ecb-bond-buying-scheme-partially-contravenes-the-law/a-53333374] accessed on 09/07/2021.

34 -[https://www.dw.com/en/top-german-court-rejects-challenge-to-ecb-bond-buyingscheme/a-57566117\#: :text=Top\%20German $\% 20$ court $\% 20$ rejects $\% 20$ challenge $\% 20$ to $\% 20$ ECB $\% 20$ bond-buying $\% 20$ scheme,-Germany $\% 27 \mathrm{~s} \% 20$ Constitutional\%20Court\&tex$\mathrm{t}=$ The $\% 20$ Constitutional $\% 20$ Court $\% 20$ in $\% 20$ the,Bank\%20(ECB)\%20was\%20acceptable] accessed on 09/07/2021.

35 Leitsätze zum Urteil des Zweiten Senats vom 5. Mai 2020 - [https://www.bundesverfassungsgericht.de/SharedDocs/Entscheidungen/DE/2020/05/rs20200505_2bvr085915.html] accessed on 09/07/2021.

36 [https://www.dw.com/en/european-court-of-justice-slams-top-german-courts-ecb-ruling/a-53371145] accessed on 09/07/2021.
} 
primacy, effectiveness, and uniform application of Union law as well as the values laid down in Article 2 TEU, including in particular the rule of law. ${ }^{37}$

Certain social tasks facing this state of contradiction between supranational regulations and fragmentation identity are common to all EU countries. One of such tasks is to protect the economic rights, freedoms, and legitimate interests of citizens and people from imbalances in development.

National public laws are such a mechanism to ensure the implementation of this task. Modern public law regulation in the paradigm of human rights and the rule of law strives for universality and generality, in the context of ECHR and ECJ judgments, but it should be restrained by the framework of sovereignties in the election of methods in the legal regulation of the state, society, and culture.

Often, such a systems confrontation leads to the consequences as the collisions of the colonizing public law and society. The most significant demonstration of resistance to suppression is the emergence of "virtual states" going beyond the jurisdictions of states and most urgently requiring a common legal platform for conflict resolution and Safety, Security, and Justice achievement. The ideology of such a platform in an open society is changing, and the mechanisms of its influence are universal. But at the interstate level, they are still subject to the traditions and experience of the states and require comprehension of the changes through the creation of a uniform universal platform of EU law regulation.

Colonizing National Public Law means certain attack on its purity and clear subject as Law on Sovereignty. One considering emerging issues in modern EU justice has to analyze semiotic and narrative tendencies in legal policy associated with diversification of the sense of supranational to administrative and disciplinary practices.

The next path is the narrative approach. We know that people and states differ from each other. National sovereignties are constructed on their own cultural and religious backgrounds (civilizational methodology) that differ from the state and interstate ones.

While we want to harmonize the EU and national approach speaking about convergencies of sovereignties on the level of legal dynamics and ideology, we should simultaneously divide and unite them. New actors in informational society require a new seat at public law balances and distribution of powers' context. These attempts to take over public law tendency are stable and popu-

37 Commission closes infringement procedure based on formal commitments of GERMANY clearly recognising the primacy of EU law and the authority of the Court of Justice of the European Union [https://ec.europa.eu/commission/presscorner/detail/en/inf_21_6201?fbclid=IwAR1w6wbHhdcA5vxlqXTohUjxcgF7mJbpSBxTXjxaNWXpMJ0MIzb9Zyuwv7I] 
lar at the international level (just remember social network role and influence on electoral processes, etc). Now the usage of a new methodological approach (triangle or holistic) formats legality depending on diverse narratives of law enforcement and judiciary. The EU Law in action needs protective usage of new approaches from the modern economy, psychiatry, neuroscience, sociology, political science considered from the limits of internationally recognized substantive forms of conduct that are necessary to regulate, margins of responsibility, and the nature of oppression in comparison with international security measures and restitution on different narrative and national level.

This requires special attention to the issue of awareness of the EU jurisprudence in economy regulating.

Thus, EU Law in its modern rewriting has to:

1. identify models for improving the public law legislation of states based on the current paradigms of Human Rights and the Rule of Law, on the basis of an integrated analysis of the EU economic development;

2. determine changes in social expectations depending on global, national, regional social changes, identify the main directions of harmonious dynamics of public law regulation at all levels of jurisdiction using modern capabilities of Big Data, on the basis of analysis of social networks, as a display of intellectual and emotional reactions to safety and security encroachments (or such expectations), as well as social assessments of injustice;

3. abandon the understanding of public law regulation as a state influence on their citizens, but to see it more broadly in the context of the development of securities phenomenon and the safety of the EU systems and values.

Being aware of this data, we should evaluate it as a factor, entailing to imbalances of what is right and what is wrong described on different levels of social interaction.

\subsection{PANDEMIC COVID 19 AND MODERN MONETARY REGULATION IN THE EUROZONE}

Even though the ECB was aimed at normalizing its asset purchases, 2020 presented changes in plans. The COVID 19 crisis has demanded new solutions from governments. In particular, the ECB has also taken significant measures to overcome the crisis. The ECB has implemented a set of monetary policy measures to reduce the negative impact of the pandemic on the European economy and to support the EU citizens. In particular, on March 18, 2020, it was decided to launch a new temporary purchase program for private and 
public sector securities to decrease risks for the monetary policy transmission mechanism and the euro area's prospects posed by the outbreak and the growing spread of COVID-19.

Also, the Governing Board made the following statement "The Governing Board will do whatever is necessary within its mandate. The Governing Board is fully committed to increasing the size of its asset purchase programs and adjusting their composition as much and as much as necessary. We will explore all options and all contingencies to support the economy during this shock" 38 . The expansion of purchases under the Pandemic Emergency Purchase Program (PEPP) confirms these intentions, as the original amount was 750 billion euros, but then it was increased by 600 billion euros on June 4, 2020, and by 500 billion euros on December 10, 2020, and as a result amounted to 1,850 billion euros. The increase in purchases came in response to the downward revision of inflation over the forecast horizon. All asset categories meeting the requirements of the existing Asset Purchase Program (APP) are also eligible to participate in PEPP, and a waiver of eligibility requirements has been granted for Greek securities.

According to the Board of Governors, the purchases of net assets under the PEPP will continue until the ECB decides that the COVID-19 crisis phase is over, but this will definitely not happen until March 2022. Principal redemption payments on securities purchased under the PEPP will be reinvested by the end of 2023. Future contraction of the PEPP portfolio is planned to be managed to avoid interference with monetary policy. ${ }^{39}$

Most likely, in the case of PEPP, precedents, and lawsuits are also possible soon, since, for example, the German constitutional court in relation to the PSPP program considered it disproportionate due to its indirect effects. Likewise, the current program PEPP that was adopted in a pandemic situation could also be considered disproportionate, for example in a proportionality check by the European Court of Justice, despite the fact that the situation required much more daring action than during the PSPP.

In March 2020, the ECB announced that net purchases under the Asset Purchase Program (APP) would continue at a monthly rate of $€ 20$ billion, along with purchases under an additional $€ 120$ billion interim package until the end of the year. Under this program, the ECB decided to expand the range of eligible assets under the Corporate Sector Purchase Program (CSPP) to non-finan-

38 [https://www.ecb.europa.eu/press/pr/date/2020/html/ecb.pr200318_1 3949d6f266. en.html] accessed on 10/07/2021.

39 [https://www.ecb.europa.eu/mopo/html/index.en.html] accessed on 16/07/2021. 
cial commercial securities, making all commercial paper of sufficient quality eligible for purchase under the CSPP ${ }^{40} 41$

Also, amid the pandemic, the ECB keeps its key interest rates at historically low levels. The interest rate on the main refinancing activities and the interest rates on the margin credit line and the deposit line will remain unchanged at $0 \%, 0.25 \%$, and $-0.50 \%$, respectively. The Governing Council expects the ECB's key interest rates to remain at or below current levels until the inflation forecast steadily approaches a level close enough to, but below $2 \%$, within its forecast horizon, which will poison the dynamics of core inflation. ${ }^{42}$

Unconventional monetary policy created new systemic risks that arose as a result of a sharp increase in the balance sheet of central banks, the propensity of economies to cheap financing, and the exhaustion of opportunities for further monetary stimulation in conditions of too-low interest rates, in the event of future crises.

Overly stimulating monetary policy in the face of strong expansion of central bank balance sheets can lead to overheating of the economy, high inflation, or asset bubbles. Central bank balance sheets are extremely large and this means that central banks will have serious problems on their way to normalizing monetary policy. The main problems will be large-scale adjustments in securities prices, it is possible that inflation will rise above the targets of central banks, due to an increase in government bond yields, a sovereign debt crisis may re-emerge. In particular, today, most of the countries of the euro area have public debt exceeding the prescribed 60\% of GDP according to the Maastricht criteria. In 2020, the growth of public debt is especially noticeable as the average for the Eurozone, the indicator of which has already reached $100 \%$ of GDP, Germany still retains the lowest indicator, $74 \%$, and Italy has the highest at over $160 \%$. And despite the fact that unconventional monetary policy stimulates economic development, it also generates significant risks.

\section{CONCLUSIONS}

The system of monetary regulation of the EU was formed evolutionarily. The European System of Central Banks has been created by strengthening cooper-

\footnotetext{
40 [https://www.ecb.europa.eu/mopo/html/index.en.html] accessed on 17/07/2021.

${ }^{41}$ Benigno, P.; Canofari, P.; Di Bartolomeo, G.; Messori, M.: The ECB's Measures in Support of the COVID-19 Crisis, Publication for the committee on Economic and Monetary Affairs, Policy Department for Economic, Scientific and Quality of Life Policies, European Parliament, Luxembourg. 2021, p. 1-29.

42 [https://www.ecb.europa.eu/mopo/html/index.en.html] accessed on 16/07/2021.
} 
ation between national central banks to coordinate monetary policy and manage the common currency. In this system, national central banks are independent in solving their own problems, but at the same time, they are an integral part of the Eurosystem. The ECB does not exercise direct control over their activities but monitors the implementation of decisions and issues appropriate recommendations. These actions determine the influence of monetary factors on the development of countries, in particular, they perform functions such as forming the value of capital, creating favorable conditions for access to financial resources, and regulating business activity. The 2008 global financial crisis led to the transformation of the monetary regulation system. Monetary regulators of many developed countries began to apply new methods, which in the economic publications are called "unconventional monetary policy".

As a result, since 2008, the European Central Bank has pursued unconventional monetary policies by combining different types of previous guidance, credit policies, quantitative easing, and negative interest rates. The European Central Bank helped to resolve crisis situations in individual states in 2008 and 2012 in order to stabilize the general economic situation in the monetary union by creating reserve funds, changing interest rates, providing loans to the banking sector, and conducting transactions with government bonds.

Today, unconventional monetary policy remains relevant for the ECB. But the transition of developed countries in early 2020 to a new phase of quantitative easing is taking place in conditions when a full-fledged exit from the previously pursued monetary stimulus policy has not yet taken place. This means that developed countries continue to be in the zero-interest rate zone, which in theory is considered a "liquidity trap". Based on this, the possibility of applying interest rate policy measures is now much less than on the eve of the global financial crisis. It should also be noted that when interest rates are very low, governments have no incentive to cut their debt and in fact have more incentive to borrow. This is a significant challenge for further monetary regulation.

The transformation of monetary regulation instruments causes changes not only in the economy but in the legal structure it gives rise to precedents in the confrontation between national and supranational legal systems. This is supported by the controversial ruling on the competence of the European Central Bank to conduct public sector asset purchases (PSPP) and the European Commission's intention to initiate proceedings in response to this decision, which calls into question the EU legal order. However, it should be noted that judicial intervention in monetary policy is an exceptional case and has a European specificity, which is associated with the actions of the ECB in the post-crisis period. Also, it can be risky to manage macroeconomics through constitutional law, as a given set of rules can only fit in certain circumstances. All this creates the basis for a possible transformation of legal regulation in the EU. 


\section{LITERATURE}

1. Abbassi, P.; Linzert T.: The effectiveness of monetary policy in steering money market rates during the financial crisis, Journal of Macroeconomics, 342012 , p. 945-954.

2. Acharya, V.; Eisert, T.; Eufinger, C.; Hirsch C.: Whatever it takes: The real effects of unconventional monetary policy, The Review of Financial Studies, 32 (9) 2019, p. 3366--3411.

- DOI: https://doi.org/10.1093/rfs/hhz005

3. Alekseievska, H.; Kyfak, A.; Rodionova, T.; Yakubovskiy, S.: Modeling Outcomes of Unconventional Monetary Policy, International Journal of Recent Technology and Engineering (IJRTE). 1(4) 2019, [10.35940/ijrte.D4503.118419], p. 1026310268.

- DOI: https://doi.org/10.35940/ijrte.D4503.118419

4. Alekseievska, H.; Mumladze, A.: Quantitative Easing as The Main Instrument of Unconventional Monetary Policy, Three Seas Economic Journal, 1 2020, [https:// doi.org/10.30525/2661-5150/2020-1-7], p. 39-46.

- DOI: https://doi.org/10.30525/2661-5150/2020-1-7

5. Arestis, P.; Sawyer, M.: A Critical reconsideration of the foundations of monetary policy in the new consensus macroeconomic framework, Cambridge Journal of Economics, 32 2008, p. 5.

- DOI: https://doi.org/10.1093/cje/ben004

6. Asshoff, S.; Belke, A.; Osowski, T.: Unconventional monetary policy andinflation expectations in the Euro area, CEPS Working Documents, 12020 , p. 1-35.

7. Benigno, P.; Canofari, P.; Di Bartolomeo, G.; Messori, M.: The ECB’s Measures in Support of the COVID-19 Crisis, Publication for the committee on Economic and Monetary Affairs, Policy Department for Economic, Scientific and Quality of Life Policies, European Parliament, Luxembourg. 2021.

8. Burriel, P.; Galesi, A.: Uncovering the heterogeneous effects of ECB unconventional monetary policies across euro area countries, European Economic Review, 101 2018, p. 210-229.

- DOI: https://doi.org/10.1016/j.euroecorev.2017.10.007

9. Carstensen, M. B,; Schmidt, V. A.: Power and changing modes of governance in the euro crisis, Governance, 31 2017, [10.1111/gove.12318] p. 609-624.

- DOI: https://doi.org/10.1111/gove.12318

10. Ciccarelli, M., Garc'1a, J. A., Montes-Gald'on, C.: Unconventional monetary policy and the anchoring of inflation expectations. European Central Bank Technical Report, 1995 2017, p. 1-33.

- DOI: https://doi.org/10.2139/ssrn.2910910 
11. Dominese, G., Yakubovskiy, S., Rodionova, T., Derenko, V. Determinants of the government bond yields of Italy, Spain, Portugal and Greece. Journal Global Policy and Governance, 10(1) 2021, [https://doi.org/10.14666/2194-7759-10-1-002] p. 23-34.

12. Dominese G., Rodionova T., Tsviakh A. Comparative Analysis of the Return on Foreign Investments of the United States, Germany and Japan. Journal Global Policies and Governance, 9(2) 2020, [https://doi.org/10.14666/2194-7759-9-2002] p. 17-27.

13. Elbourne, A.; Ji K.; Duijndam S.: The effects of unconventional monetary policy in the euro area. CPB Discussion Paper, 371 2018, p. 1-36

14. Gambetti, L.; Musso, A.: The macroeconomic impact of the ECB's expanded asset purchase programme (APP). European Central Bank Working Paper Series, 2075 2017, p. 1-43.

- DOI: https://doi.org/10.2139/ssrn.2985385

15. Holman O.: Asymmetrical regulation and multidimensional governance in the European Union. Review of International Political Economy, 2024, [10.1080/ 096922904200027977] p. 714-735.

- DOI: https://doi.org/10.1080/0969229042000279775

16. Kovalenko, V.; Sheludko, S.; Slatvinska, M.; Sergeeva O.; Kulikova Ye: Monetary regulation in the economic growth of a state. Financial and credit activities: problems of theory and practice, 3 (34) 2020, p. 70-80.

- DOI: https://doi.org/10.18371/fcaptp.v3i34.215411

17. Lomachynska, I., Babenko, V., Yemets Impact of the Foreign Direct Investment Inflow on the Export Growth of the Visegrad Group Countries. Studies of Applied Economics, [http://dx.doi.org/10.25115/eea.v38i4.4007] 38 (4) 2020.

- DOI: https://doi.org/10.25115/eea.v38i4.4007

18. Mouabbi, S., Sahuc, J. G. Evaluating the macroeconomic effects of the ECB's unconventional monetary policies. Journal of Money, Credit and Banking. 51 (4) 2019, p. 831-858.

- DOI: https://doi.org/10.1111/jmcb.12628

19. Piodi F.: The long road to the euro. Cardoc Journals, 8 2012, p. 1-252.

20. Salter, A. W.: An Introduction to Monetary Policy Rules. Mercatus Working Paper, 12(04) 2014, [http://dx.doi.org/10.2139/ssrn.3191382], p. 1-41.

- DOI: https://doi.org/10.2139/ssrn.3191382

21. Tuliakov V.A.: The dualism of business victimization and organized crime, Trends in Organized Crime, 6, 2001 [https://doi.org/10.1007/s12117-001-1008-4] p. 94-99.

- DOI: https://doi.org/10.1007/s12117-001-1008-4

22. Yakubovskiy, S.; Alekseievska, H.; Tsevukh J.: Impact of the European Central Bank Monetary Policy on the Financial Indicators of the Eastern Europe- 
an Countries. Journal Global Policy and Governance, 9 (1) 2020. [https://doi. org/10.14666/2194-7759-9-1-003]

23. Zabala, J. A.; Prats, M. A.: The unconventional monetary policy of the European Central Bank: Effectiveness and transmission analysis. The World Economy, 43 2019.

- DOI: https://doi.org/10.1111/twec.12880

\section{LEGAL ACTS}

1. Council Decision of 8 May 1964 on co-operation between the Central Banks of the Member States of the European Economic Community, 1964. [http://eur-lex. europa.eu/legal-content/EN/TXT/PDF/?uri=CELEX:31964D0300\&from=EN] accessed on 09/07/2021.

2. Protocol No 4 on the Statute of the European System of Central Banks and of the European Central Bank (2002). Consolidated version of the Treaty on the Functioning of the European Union. [https:/eur-lex.europa.eu/legal-content/EN/TXT/ HTML/?uri=CELEX:12016E/PRO/04\&from=EN] accessed on 09/07/2021.

3. The Treaty on European Union, as signed in Maastricht on 7 February 1992. [http:// europa.eu/eu-law/decision-making/treaties/pdf/treaty_on_european_union/ treaty_on_european_union_en.pdf] accessed on 09/07/2021

4. Leitsätze zum Urteil des Zweiten Senats vom 5. Mai 2020 - [https://www.bundesverfassungsgericht.de/SharedDocs/Entscheidungen/DE/2020/05/rs20200505_ 2bvr085915.html] accessed on 09/07/2021.

\section{ONLINE SOURCES}

1. Consolidated version of the Treaty on the Functioning of the European Union, 2002. [http://eur-lex.europa.eu/legal-content/EN/TXT/PDF/?uri=CELEX:12002E/ TXT\&from $=E N]$ accessed on 09/07/2021.

2. Deutsche Welle (2020). Top German court says ECB bond buying scheme partially contravenes the law [https://www.dw.com/en/top-german-court-says-ecb-bondbuying-scheme-partially-contravenes-the-law/a-53333374] accessed on 09/07/2021.

3. Deutsche Welle (2021a). Top German court rejects challenge to ECB bond-buying scheme [https://www.dw.com/en/top-german-court-rejects-challenge-to-ecb-bondbuying-scheme/a-57566117\#: :text=Top\%20German\%20court\%20rejects\%20challenge $\% 20$ to $\% 20 \mathrm{ECB} \% 20$ bond-buying\%20scheme,-Germany $\% 27 \mathrm{~s} \% 20$ Constitutional\%20Court\&text=The $\% 20$ Constitutional $\% 20$ Court $\% 20$ in $\% 20$ the,Bank $\% 20$ (ECB)\%20was\%20acceptable] accessed on 09/07/2021.

4. Deutsche Welle (2021b). European Court of Justice slams top German court's ECB ruling [URL:https://www.dw.com/en/european-court-of-justice-slams-topgerman-courts-ecb-ruling/a-53371145] accessed on 09/07/2021. 
5. ECB announces $€ 750$ billion Pandemic Emergency Purchase Programme (PEPP). 2020. The official site of the European central bank [https://www.ecb.europa.eu/press/pr/date/2020/html/ecb.pr200318_1 3949d6f266.en.html] accessed on $10 / 07 / 2021$.

6. European central bank. Monetary policy 2021. [https://www.ecb.europa.eu/mopo/ html/index.en.html ] accessed on 16/07/2021.

7. ReportonEconomic and Monetary Union.The official site of the EuropeanCommission [http://ec.europa.eu/economy_finance/publications/pages/publication6161_ en.pdf] accessed on 09/07/2021.

8. Report to the Council and the Commission on the realization by stages of Economic and Monetary Union. (1970) Archive of European Integration [http://aei. pitt.edu/1002/1/monetary_werner_final.pdf] accessed on 19/07/2021.

9. Speech by Mario Draghi, President of the European Central Bank at the Global Investment Conference in London 26 July 2012. The official site of the European central bank [https:/www.ecb.europa.eu/press/key/date/2012/html/sp120726. en.html] accessed on 09/07/2021.

10. Commission closes infringement procedure based on formal commitments of GERMANY clearly recognising the primacy of EU law and the authority of the Court of Justice of the European Union [https://ec.europa.eu/commission/presscorner/detail/en/inf_21_6201?fbclid=IwAR1w6wbHhdcA5vxlqXTohUjxcgF7mJbpSBxTXjxaNWXpMJ0MIzb9Zyuwv7I] accessed on 03/12/2021. 